\title{
A Previously Undiagnosed Case of Alkaptonuria: A Case Report
}

\author{
Daha Önce Tanı Konulmamış Alkaptonüri: Olgu Sunumu \\ Mohammed ALSBOU, Nesrin MWAFI \\ Faculty of Medicine, Mutah University, Alkaptonuria Research Office, Karak, Jordan
}

\begin{abstract}
Alkaptonuria is a rare metabolic disorder in the phenylalanine and tyrosine catabolic pathway which is characterized by the excessive excretion of homogentisic acid in the urine, ochronosis, and debilitating arthritis of the spine and large joints. Although it is a very rare disease in most ethnic groups, it is more common in some countries, such Slovakia and the Dominican Republic. In this report, we report a 58-year-old Jordanian female case with advanced clinical features of alkaptonuria.
\end{abstract}

Key words: Alkaptonuria; arthritis; dark urine; homogentisic acid; pigmentation.

Alkaptonuria (AKU) is a rare metabolic, autosomal recessive disorder in the phenylalanine and tyrosine catabolic pathway that is characterized by the accumulation of homogentisic acid (HGA; homogentisic aciduria) in the body, especially in the connective tissues (cartilage, tendons, and ligaments) ${ }^{[1]}$ Alkaptonuria is caused by mutations in the homogetisate 1.2-dioxygenase gene (HGD), which lead to a lack of HGD enzyme activity. ${ }^{[2,3]}$ Furthermore, in this disease, excessive HGA is converted to a polymeric melaninlike pigment that binds to all connective tissues in a pathophysiological process called ochronosis. ${ }^{[4]}$ The total number of identified AKU-causing mutations worldwide is 115 , and up-to-date information can be found in the AKU mutation database. ${ }^{[5]}$

The major clinical manifestations of the disease are dark urine, usually present at birth, ochronosis (blue-dark pigmentation of connective tissues), and
Alkaptonüri, idrardan çok miktarda homogentisik asit atılımı, okronozis ve omurga ve büyük eklemlerde tahrip edici artrit ile karakterize, fenilalanin ve tirozin katabolik yolağında nadir görülen bir metabolik bozukluktur. Birçok etnik grupta çok nadir görülse de, Slovakya ve Dominik Cumhuriyeti gibi bazı ülkelerde daha sık karşılaşılır. Bu yazıda, alkaptonürinin ileri klinik özelliklerini taşıyan 58 yaşında Ürdünlü bir kadın olgu sunuldu.

Anahtar sözcükler: Alkaptonüri; artrit; koyu idrar; homogentisik asit; pigmentasyon.

ochronotic arthropathy, which especially affects the large weight-bearing joints and spine and typically appears after the age of thirty. ${ }^{[6]}$ Complications of AKU begin after the age of 50 and include stone formation (renal, prostatic, gall bladder, and salivary) along with cardiac valve involvement, particularly aortic valve disease. ${ }^{[7]}$

The prevalence of $A K U$ is unknown in the Jordanian population. However, recent published studies have reported a high incidence rate in this country. For example, 40 cases with AKU have been reported in the southern region of Jordan ${ }^{[8]}$ with most of these being undiagnosed or misdiagnosed cases found in specific families. Of these cases, nine were identified in just one family. ${ }^{[9]}$

In this article, we present an advanced case of AKU with typical clinical manifestations in southern

Received: May 20, 2012 Accepted: September 12, 2012

Correspondence: Mohammed Alsbou, M.D. Faculty of Medicine, Mutah University, Alkaptonuria Research Office, 61710 Karak, Jordan. Tel: +962795754724 e-mail: malsbou@mutah.edu.jo

(O2013 Turkish League Against Rheumatism. All rights reserved. 
Jordan in which we describe the clinical, biochemical, and radiological findings.

\section{CASE REPORT}

We present the case of a 58-year-old female with a 10-year history of severe chronic lower back and morning stiffness. The patient's pain became more exacerbated upon the initiation of spinal movements and flexion of the spinal column. She had no symptoms of nerve root compression but had a history of large joint pain in her hips, knees, and shoulders. A physical examination revealed bluish pigmentation over the forehead, cheeks, nose, fingertips, nails, hands, and ear cartilage (Figure 1). In addition, the sclera of both eyes showed dark brown pigment deposits, and there was dark brown pigmentation of the skin, teeth, and gums. When the patient's urine was left standing for a few hours at room temperature, it turned dark. Furthermore, a dark color was also obtained when ferric chloride was added to the urine sample (Figure 2). According to the clinical examination, the patient had bilateral fixed flexion deformity in both hips with decreased flexion-extension motion with no abduction or adduction. She also had 30-degree fixed flexion bilateralvarus knee deformity with decreased flexionextension range of motion. Additionally, the patient had a fixed kyphotic thoracic spine with decreased lateral flexion in both directions. Regarding her upper limbs, she had normal shoulder range of motion with minimal tenderness in abduction, and both elbows had normal flexion-extension range

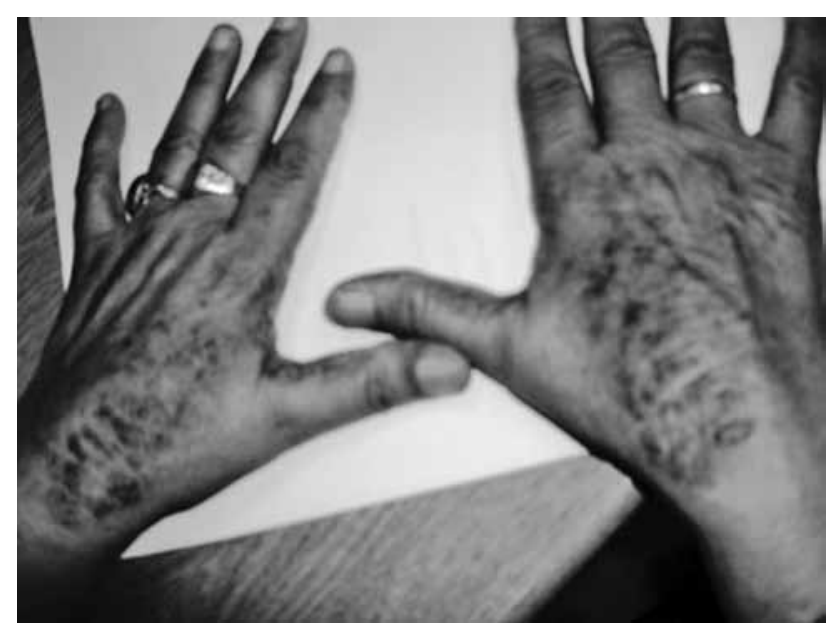

Figure 1. Hyperkeratotic bluish-dark pigmented papules over the lateral side of the dorsum and lateral side of the wrist of both hands as well as in the web between the thumb and index finger. of motion along with a $50 \%$ decrease in pronationsupination. Exaggerated thoracic kyphosis and loss of height were also noted.

Radiographs of the lumbar spine showed extensive degenerative changes with severe narrowing of the joint spaces together with intervertebral disc calcification along the lumbar spine, fusion of vertebral bodies in the upper lumbar spine, osteophyte and bone bridge formation, and loss of lumbar lordosis (Figure 3). Additionally, an $\mathrm{X}$-ray of the knee joints determined that there were degenerative changes with joint space narrowing, and X-rays of both shoulders showed decreased joint spaces with degenerative changes in the articular portion of the humeral head. The patient also complained of difficulty walking and of an inability to move. Eventually, she became disabled. The patient used to have high-protein content meals but had changed her diet to one of low protein since being diagnosed with AKU. She was also prescribed $1 \mathrm{~g}$ of vitamin $\mathrm{C}$ daily. She has 13 children (two sons and eleven daughters), and there is a family history of AKU, with two sons and six daughters having also been diagnosed with the same disease.

\section{DISCUSSION}

Although AKU is a rare genetic disorder that is found all over the world ( 1 in 250,000), high incidence rates have been reported in countries such as Slovakia (1 in 19,000) and the Dominican Republic, ${ }^{[10,11]}$ and so far, 626 patients with AKU have been identified in 40 different countries. ${ }^{[12]}$ In Jordan, the preliminary results of targeted family screening have identified 64 cases. This large number of AKU patients in a small

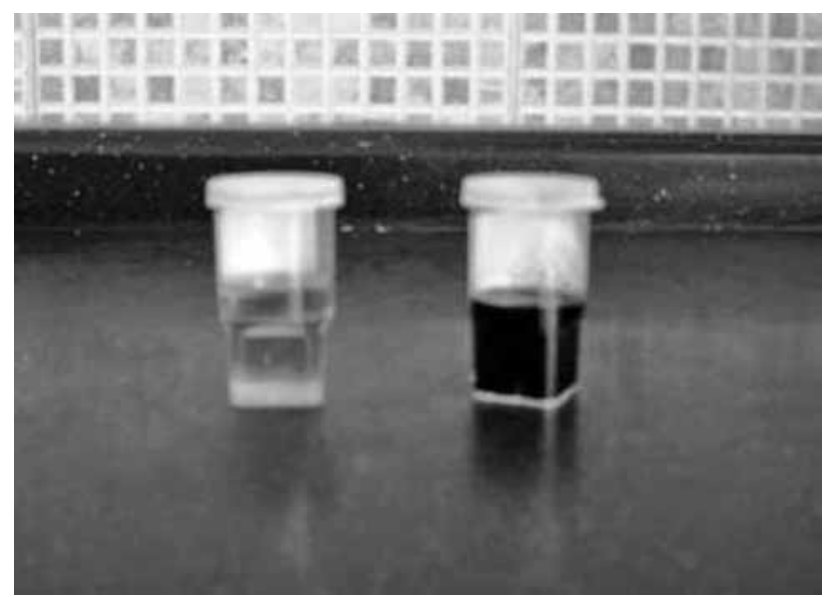

Figure 2. Patient's urine before (left) and after adding ferric chloride (right). 


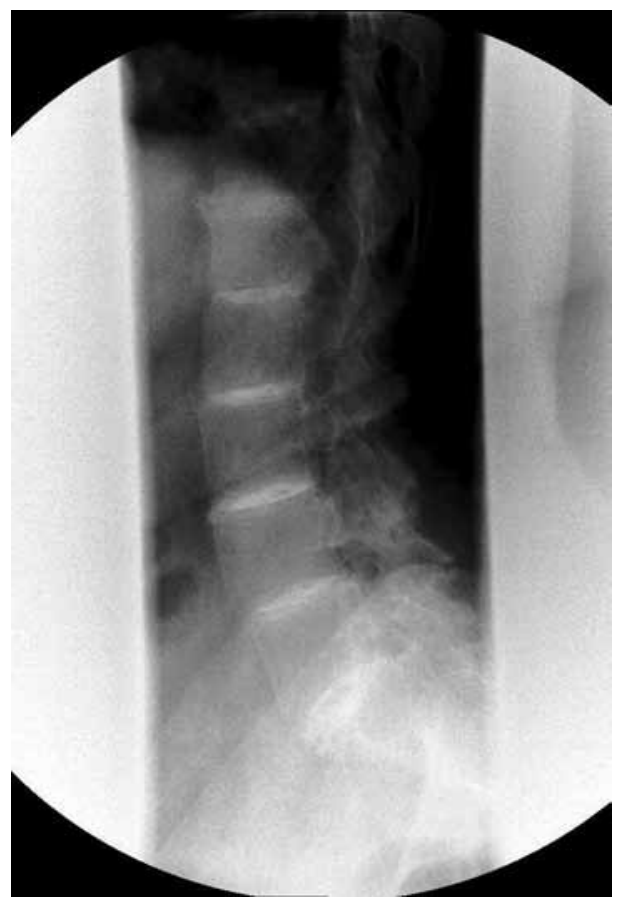

Figure 3. X-ray of the lumbar spine showing extensive degenerative changes with severe narrowing of the intervertebral spaces and intervertebral disc calcification along the lumbar spine.

country with a population of only five million is due to the large number of consanguineous marriages. ${ }^{[9]}$

In this study, we reported on our experience with a patient who had an advanced case of AKU that had previously gone undiagnosed. Because the diagnosis occurred at the relatively late age of 58 , the main characteristic features of the disease, such as involvement of the spine, hips, and knees along with the typical radiological signs were already present. Ochronotic spondyloarthropathy is the most common complication of AKU. This occurs due to the deposition of ochronotic pigment in the intervertebral discs and articular cartilage of the large joints. ${ }^{[13]}$ Ochronotic spondyloarthropathy resembles ankylosing spondylitis (AS) in its damage to the spine and large joints; however, it differs in that it spares the sacroiliac joints and does not have the annular ossification, syndesmosis, or bamboo spine that are associated with AKU. ${ }^{[14]}$ In addition, AS is also indicated by the appearance of thin, vertical syndesmophytes, severe involvement of the apophyseal facet joints, and erosion and fusion of the sacroiliac joints. ${ }^{[15]}$

Spinal changes that occur with AKU include severe disc calcification, disc space narrowing, and sclerosis, primarily in the dorsolumbar spine rather than the lumbosacral spine. ${ }^{[16]}$ The calcification of intervertebral discs is pronounced at the periphery and tends to spare the central nucleus pulposus, with its wafer-like pattern. ${ }^{[17]}$ Large peripheral joint involvement usually takes place years after ochronotic spinal involvement, and the small joints of the hands and feet, wrists, elbows and ankles are rarely affected. The knees are the most frequent target, and knee joint effusion may also occasionally occur. After the knees, the hips are affected the most, and rapid deterioration is often seen in these joints with AKU. ${ }^{[18]}$

No effective treatment exists for AKU. What is currently offered is primarily supportive in nature and includes genetic counseling, pain management with nonsteroidal anti-inflammatory drugs (NSAIDS), and physiotherapy. It has been reported that avoiding a diet high in phenylalanine and tyrosine may be helpful. ${ }^{[19,20]}$ A few studies have also suggested that vitamin $\mathrm{C}$ might be beneficial because it prevents the oxidation of HGA, thus preventing the deposition of ochronotic pigments. ${ }^{[21]}$ However, no clinical studies have shown the longterm efficacy of these modalities. A drug called nitisinone has also been mentioned as a potential treatment for AKU; however, the long-term clinical efficacy and safety of this drug have also not been demonstrated. ${ }^{[22]}$ In severe cases of AKU, surgical intervention is required to replace the severely affected joints.

Physicians involved in the care of patients with musculoskeletal problems should be aware of this rare genetic disease, particularly if a degenerative arthropathy is far more progressed than would be expected for the patient's age.

\section{Acknowledgement}

The authors would like to thank the Deanship of Academic Research at Mutah University for providing funding to the Alkaptonuria research project in Jordan.

\section{Declaration of conflicting interests}

The authors declared no conflicts of interest with respect to the authorship and/or publication of this article.

\section{Funding}

The authors received no financial support for the research and/or authorship of this article. 


\section{REFERENCES}

1. Idem. The Croonian lectures on inborn errors of metabolism. Lecture II. Alkaptonuria. Lancet, 1908;2:73-9.

2. LA DU BN, Zannoni VG, Laster L, Seegmiller JE. The nature of the defect in tyrosine metabolism in alcaptonuria. J Biol Chem 1958;230:251-60.

3. Fernández-Cañón JM, Granadino B, Beltrán-Valero de Bernabé D, Renedo M, Fernández-Ruiz E, Peñalva MA, et al. The molecular basis of alkaptonuria. Nat Genet 1996;14:19-24.

4. Keller JM, Macaulay W, Nercessian OA, Jaffe IA. New developments in ochronosis: review of the literature. Rheumatol Int 2005;25:81-5.

5. Zatkova A. An update on molecular genetics of Alkaptonuria (AKU). J Inherit Metab Dis 2011;34:112736. doi: 10.1007/s10545-011-9363-z.

6. Ladjouze-Rezig A, Rodriguez de Cordoba S, Aquaron R. Ochronotic rheumatism in Algeria: clinical, radiological, biological and molecular studies--a case study of 14 patients in 11 families. Joint Bone Spine 2006;73:284-92.

7. Pettit SJ, Fisher M, Gallagher JA, Ranganath LR. Cardiovascular manifestations of Alkaptonuria. J Inherit Metab Dis 2011;34:1177-81. doi: 10.1007/s10545011-9339-z.

8. Al-Sbou M, Mwafi N, Lubad MA. Identification of forty cases with alkaptonuria in one village in Jordan. Rheumatol Int 2012;32:3737-40. doi: 10.1007/s00296011-2219-x.

9. Al-Sbou M, Mwafi N. Nine cases of Alkaptonuria in one family in southern Jordan. Rheumatol Int 2012;32:621-5. doi: 10.1007/s00296-010-1701-1.

10. Milch RA. Studies of Alcaptonuria: Inheritance of 47 Cases in Eight Highly Inter-related Dominican Kindreds. Am J Hum Genet 1960;12:76-85.

11. Srsen S, Cisárik F, Pásztor L, Harmecko L. Alkaptonuria in the Trencín District of Czechoslovakia. Am J Med Genet 1978;2:159-66.
12. Ranganath L, Taylor AM, Shenkin A, Fraser WD, Jarvis J, Gallagher JA, et al. Identification of alkaptonuria in the general population: a United Kingdom experience describing the challenges, possible solutions and persistent barriers. J Inherit Metab Dis 2011;34:723-30. doi: 10.1007/ s10545-011-9282-z.

13. Fisher AA, Davis MW. Alkaptonuric ochronosis with aortic valve and joint replacements and femoral fracture: a case report and literature review. Clin Med Res 2004;2:209-15.

14. EmelE, KaragözF, Aydín IH, Hacísalihoğlu S, Seyithanoğlu MH. Alkaptonuria with lumbar disc herniation: a report of two cases. Spine (Phila Pa 1976) 2000;25:2141-4.

15. Corrà T, Zaccala M, Galante M. Ochronotic arthropathy: rapid destructive hip osteoarthritis associated with metabolic disease. Clin Rheumatol 1995;14:474-7.

16. Hamdi N, Cooke TD, Hassan B. Ochronotic arthropathy: case report and review of the literature. Int Orthop 1999;23:122-5.

17. O’brien WM, La Du BN, Bunin JJ. Biochemical, pathologic, and clinical aspects of alcaptonuria, ochronosis and ochronotic arthropathy. Review of world literature. Am J Med 1963;34:813-38.

18. Mannoni A, Selvi E, Lorenzini S, Giorgi M, Airó P, Cammelli D, et al. Alkaptonuria, ochronosis, and ochronotic arthropathy. Semin Arthritis Rheum 2004;33:239-48.

19. Wolff JA, Barshop B, Nyhan WL, Leslie J, Seegmiller JE, Gruber $\mathrm{H}$, et al. Effects of ascorbic acid in alkaptonuria: alterations in benzoquinone acetic acid and an ontogenic effect in infancy. Pediatr Res 1989;26:140-4.

20. de Haas V, Carbasius Weber EC, de Klerk JB, Bakker HD, Smit GP, Huijbers WA, et al. The success of dietary protein restriction in alkaptonuria patients is age-dependent. J Inherit Metab Dis 1998;21:791-8.

21. Mayatepek E, Kallas K, Anninos A, Müller E. Effects of ascorbic acid and low-protein diet in alkaptonuria. Eur J Pediatr 1998;157:867-8.

22. Introne WJ, Perry MB, Troendle J, Tsilou E, Kayser MA, Suwannarat P, et al. A 3-year randomized therapeutic trial of nitisinone in alkaptonuria. Mol Genet Metab 2011;103:307-14. doi: 10.1016/j.ymgme.2011.04.016. 